\title{
Diseño de un proceso experimental para la producción de papaína liofilizada
}

\author{
Javier Quino Favero, Nora Bernal Portilla, Juan Carlos Yácono Llanos
}

Ingeniería Industrial n. 26, 2008, ISSN 1025-9929, pp. 201-229

Resumen: Se describe el diseño de un proceso tecnológico para la obtención de papaína purificada a partir del látex fresco del fruto verde de $\mathrm{Ca}$ rica papaya. El látex fresco del fruto es resuspendido en buffer con agentes protectores de la actividad de la enzima cuya concentración y condiciones de aplicación fueron halladas de manera experimental. El extracto es centrifugado para separar la materia insoluble y la solución clarificada es sometida a precipitación con sulfato de amonio para obtener enzima insoluble. La enzima insolubilizada es resuspendida en agua, desalinizada en una unidad de filtración tangencial y el agua removida por liofilización. El proceso permite recuperar el 80\% de la proteína y el 65\% de la actividad original. El producto obtenido es un polvo blanco rápidamente soluble en agua. Todas las etapas pueden ser escaladas para la producción comercial de papaína.

Palabras clave: Papaína, proteasa, carica papaya

\section{Experimental Process design for lyophilized papain production}

Abstract: A process for papain (cistein papainase) extraction and purification from fresh latex obtained from unripped fruits of Carica papaya is described. Samples of fresh collected latex were suspended in citratephosphate buffer containing reducing agents whose concentration and application conditions were found experimentally. The extract was centrifugated and the clarified solution subjected to ammonium sulphate precipitation. The insoluble fraction was resuspended in water, desalted and concentrated by tangential filtration and, the remaining water removed by liophylization. The process allowed $80 \%$ recovery of the initial protein content and $65 \%$ of the original activity, the product obtained can be described as a white powder very soluble in water. All the steps can be scaled-up for commercial papain production.

Keywords: Papain, protease, carica papaya. 


\section{INTRODUCCIÓN}

Las enzimas son biocatalizadores, agentes de origen biológico que aceleran la velocidad a la cual ocurren las reacciones químicas al disminuir los requerimientos de energía de activación necesaria para dichas reacciones (Cornish-Bowden, 1995). Las enzimas no se consumen en el proceso, por lo que una molécula de enzima sigue actuando.

La catálisis enzimática — como se denomina a la acción de las enzimas- es eficiente, altamente específica, puede llevarse a cabo en condiciones relativamente suaves - como temperatura ambiente y $\mathrm{pH}$ neutro- y permite un control muy preciso de la reacción. Por ello, la aplicación de las enzimas a la industria se constituye en uno de los primeros procesos biotecnológicos de la química moderna (Roberts, Turner et al., 1995).

Las enzimas han encontrado un gran número de aplicaciones en la industria, una de las clases de enzimas con mayor amplitud de aplicación son las proteasas. ${ }^{1}$ Las proteasas son enzimas que provocan la hidrólisis o digestión de otras proteínas en fragmentos más pequeños y en ciertas condiciones pueden ser usadas para la síntesis de nuevos compuestos de interés farmacéutico (Chaiwut, Kanasawud et al., 2007). Una de las proteasas cuyo uso se encuentra muy difundido es la papaína, en realidad una mezcla de papaína y quimopapaína, que es extraída del látex de los frutos verdes de la Carica papaya.

Las plantas de Carica papaya tienen tallo recto, de crecimiento rápido y sin ramificaciones; de siete a ocho metros de alto y con un tallo de $20 \mathrm{~cm}$ de diámetro. Las hojas son suaves y se encuentran agrupadas cerca de la parte superior de la planta. Es nativa de América Central y se ha distribuido en los trópicos, donde se cultiva hasta 32 grados de latitud, tanto hacia el norte como hacia el sur. En algunas zonas tropicales es prácticamente una maleza.

La papaína se encuentra en el látex y se colecta haciendo cortes sagitales en los frutos verdes, este fluye después de hacer cortes superficiales, para coagularse en la superficie del fruto después de algunos minutos, en un proceso similar a lo que ocurre con las heridas (Silva,

1 Medicamentos para facilitar la digestión, manufactura de vacunas, medicación para el tratamiento de desplazamiento de discos intervertebrales, soluciones para limpieza de lentes de contacto, síntesis de péptidos y medicamentos antiinflamatorios, entre otros. 
Garcia et al., 1997). El látex gotea en un recipiente apropiado y es secado al sol o en horno a 55-60 grados. Los mismos frutos son cortados nuevamente en diferentes lugares en intervalos semanales. Estos frutos son comestibles, por lo que el látex y el fruto son utilizados. Se han reportado rendimientos de 20 a $25 \mathrm{~kg}$ de papaína seca por hectárea durante el primer año; 90 a $100 \mathrm{~kg}$ durante el segundo; 60 a $90 \mathrm{~kg}$ en el tercero; 30 a $40 \mathrm{~kg}$ en el cuarto, y 20 o menos en el quinto (Morton, 1977; Duke y DuCellier, 1993).

El 2006, el Perú importó casi tres millones de dólares en poco más de 334 toneladas de diferentes tipos de enzimas (gráfico 1). Por ello, es de interés el desarrollo de métodos de extracción y purificación avanzados para producir enzimas que satisfagan la demanda interna y que puedan - a su vez- encontrar un mercado externo.

\section{Gráfico 1}

Importación de enzimas en el Perú en los años 2003-2006



Fuente: Datatrade SAC.

Elaboración propia.

La papaína es obtenida del látex del fruto verde de la Carica papaya. La Carica es un género que se originó en América tropical y subtropical, del cual se han descrito unas 40 especies nativas desde México hasta el norte de Argentina. De estas especies la Carica papaya (papaya) es la más diseminada en los trópicos del mundo y la fuente principal de papaína. 
En la producción convencional de papaína se realiza una serie de incisiones a los frutos verdes de la papaya, los que empiezan a exudar el látex, el que es secado al sol o en hornos, previa mezcla con sulfito de potasio para evitar la oxidación; luego, el látex seco será pulverizado y vendido como papaína cruda. Este proceso deteriora una cantidad importante de la enzima presente e introduce muchas impurezas. A la fecha los principales exportadores de papaína cruda son Sri Lanka, Uganda y Tanzania (Duke, 1983).

El producto de estas exportaciones llega a países industrializados, como los Estados Unidos, en donde la papaína cruda es sometida a procesos de purificación con la finalidad de aumentar su actividad, removerle impurezas, estandarizada y aplicada a procesos industriales. La papaína cruda importada a los Estados Unidos está dentro del rubro productos hortícolas misceláneos, y como puede apreciarse en la tabla 1 el total mundial se encuentra en aumento.

Cerca del $80 \%$ de la cerveza producida en los Estados Unidos es tratado con papaína, la cual digiere los fragmentos de proteína que pueden precipitar, gracias a esta acción la cerveza se mantiene transparente cuando se enfría (Duke y DuCellier, 1993).

Los procesos destinados a la separación de la papaína del látex, purificación, concentración y estabilización aumentan significativamente el valor de la papaína cruda y le permite ingresar a mercados y procesos productivos más sofisticados. La tecnología de purificación de papaína, aún en proceso de optimización, le da un alto valor al producto, lo cual demuestra su gran rentabilidad y atractivo para los inversionistas del país. El látex (papaína cruda) es cotizado con un valor promedio aproximado de US $\$ 35 / \mathrm{kg}$, mientras que la papaína purificada puede llegar a costar US $\$ 160 / 100$ g o más para las preparaciones muy purificadas. El precio del kilo de papaya pagado al productor en el año 2002 fue de S/.0,292 por kilogramo. ${ }^{2}$ Se estima que cada fruto produce unos 9 gramos de látex por kilo (Monti, Basilio et al., 2000), y cada cajón de papaya comercializada podría producir 108 g de látex.

2 Ministerio de Agricultura del Perú. Cuadro 59. "Precio promedio pagado al productor (en chacra) por mes según principales productos agrícolas y pecuarios”. [en línea] Portal Agrario. <http://www.portalagrario.gob.pe/precios/pppagprod_0212.shtml>. (Consulta: 27 de enero del 2008). 


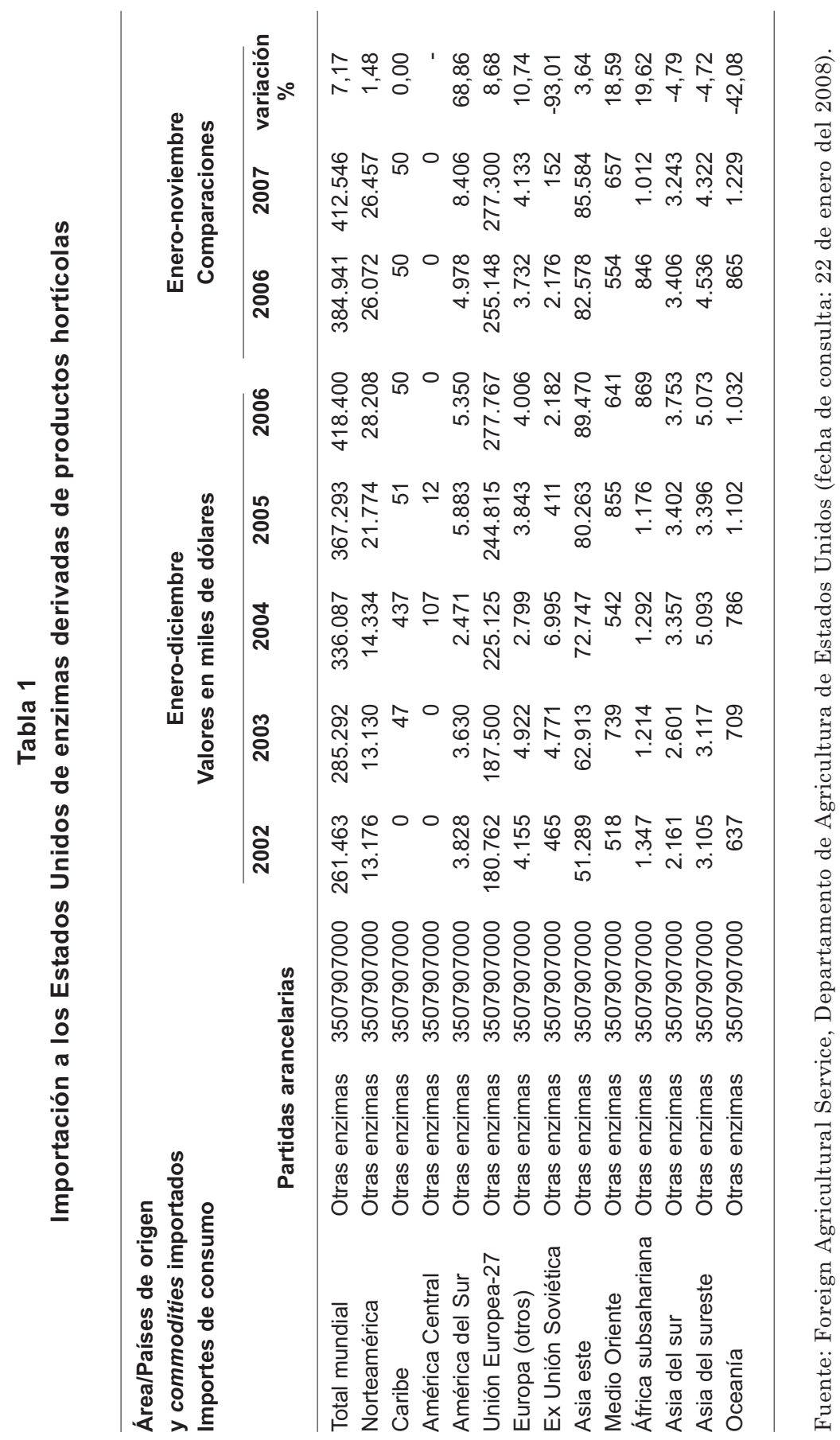


En nuestro país la disponibilidad de papaya es abundante. Existen diversas regiones, como Huánuco, Amazonas, Ucayali, donde las condiciones climatológicas favorecen el cultivo de la papaya. La necesidad de recolección del látex propicia la demanda de mano de obra, lo que crea más fuentes de trabajo para la población.

El empleo de la papaya para la producción de papaína favorece el ecodesarrollo; es decir, promueve el desarrollo de las regiones, al utilizar racionalmente los recursos naturales con estilos tecnológicos y formas de organización que respetan los patrones sociales y culturales. ${ }^{3}$

\section{MATERIAL Y MÉTODOS}

\subsection{Obtención de látex de Carica papaya}

Se obtuvo látex por incisiones longitudinales realizadas a frutos verdes de papaya (véase fotografía). La extracción se hizo entre las 9 y las 10 de la mañana, en plantas de papaya ubicadas en el distrito de San Borja, en Lima. Las incisiones se realizaron con la ayuda de una espátula plástica. El látex que emana de las incisiones fue recolectado en vasos de precipitado previamente lavados con mezcla sulfocrómica y enjuagados con agua destilada y bidestilada. Las muestras recogidas de esa manera fueron tapadas con parafilm y almacenadas en frío en una caja térmica con hielo para su transporte al laboratorio.

\subsection{Determinación de la concentración de proteína}

La determinación del contenido de proteína en el látex se realizó por el método de Lowry (Stoschek, 1990), utilizando como patrones albúmina de suero bovino (BSA Sigma) y papaína liofilizada (Sigma). El buffer alcalino consistió en $48 \mathrm{ml}$ de $\mathrm{NaOH} 0.1 \mathrm{M}$, conteniendo 2 por ciento de $\mathrm{Na}_{2} \mathrm{CO}_{3}, 1 \mathrm{ml}$ de tartrato de sodio y potasio al $1 \%$ y $1 \mathrm{ml}$ de $\mathrm{CuSO} 4 \cdot 5 \mathrm{H} 2 \mathrm{O}$ al $0.5 \%$. A $100 \mu \mathrm{L}$ de muestra se le adicionaron $2000 \mu \mathrm{L}$ de buffer alcalino y se incubó por 10 minutos a temperatura ambiente. Luego se adicionaron $200 \mu \mathrm{L}$ de reactivo Folin-Ciocalteu diluido (Sigma) 1:1, seguido de agitación inmediata en un vórtex.

3 Organización de las Naciones Unidas. "Glossary of Environment Statistics, Studies in Methods". Series F, núm. 67. Nueva York, 1997. 


\section{Incisiones en frutos de Carica papaya para obtener látex}

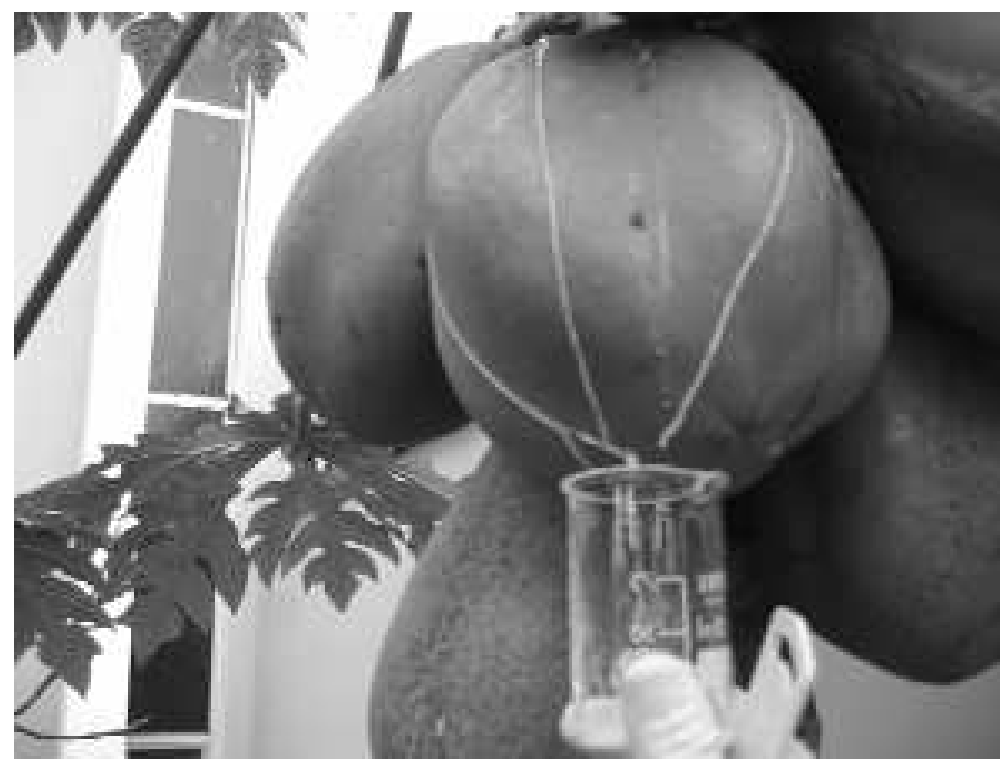

Se preparó una batería de estándares con concentraciones 0.2, 0.4, 0.6, 0.8 y 1.0 mg/ml de BSA o papaína. Se siguió el siguiente esquema:

Tabla 2

\section{Protocolo para cuantificar la cantidad de proteína}

\begin{tabular}{lcc}
\hline & Blanco & Muestra/estándar \\
\hline Agua & $100 \mu \mathrm{L}$ & \\
Muestra & - & $100 \mu \mathrm{L}$ \\
Buffer alcalino & $2.000 \mu \mathrm{L}$ & $2000 \mu \mathrm{L}$ \\
Incubar por 10 minutos a temperatura ambiente & & \\
Reactivo Folin-Ciocalteau & $200 \mu \mathrm{L}$ & $200 \mu \mathrm{L}$ \\
Incubar por 30 minutos a temperatura ambiente y leer absorbancias a 600nm
\end{tabular}




\subsection{Determinación de la actividad enzimática}

Para la determinación de la actividad se utilizó como sustrato de reacción una disolución $25 \mathrm{mM}$ de benzoíl-arginil-paranitroanilida (Bapna) (Sarath, Zeece et al., 2001), para ello se disolvió $0.1087 \mathrm{~g}$ de Bapna en $10 \mathrm{~mL}$ de dimetilsulfóxido (DMSO). Las muestras con la enzima extraída fueron resuspendidas en buffer ácido 4-morfolinoetanosulfónico (MES) $0.01 \mathrm{M} \mathrm{pH}$ 6.20, que contenía cisteína o 2-mercaptoetanol $50 \mathrm{mM}$ como agentes reductores incubadas por 10 minutos a $25^{\circ} \mathrm{C}$ antes de iniciar la reacción por adición del Bapna $25 \mathrm{mM}$. La hidrólisis del Bapna por la acción enzimática se monitoreó de manera continua a $410 \mathrm{~nm}$ en un espectrofotómetro Perkin Elmer Lambda 40. Se siguió el siguiente esquema:

Tabla 3

Protocolo para determinar la actividad enzimática

\begin{tabular}{lcc}
\hline & Blanco & Muestra/estándar \\
\hline Muestra & - & $100 \mu \mathrm{L}$ \\
Agua & $100 \mu \mathrm{L}$ & - \\
Buffer MES $0.01 \mathrm{M} \mathrm{pH} 6.20$ & $1900 \mu \mathrm{L}$ & $1900 \mu \mathrm{L}$ \\
Incubar por 10 minutos a $25^{\circ} \mathrm{C}$ & $100 \mu \mathrm{L}$ & $100 \mu \mathrm{L}$ \\
Bapna $25 \mathrm{mM}$ & & \\
Leer absorbancia de manera continua a $410 \mathrm{~nm}$ y calcular la pendiente en el rango lineal. \\
\hline
\end{tabular}

La variación de la absorbancia con respecto al tiempo (dA/dt) permite calcular la tasa de formación de p-nitroanilida con respecto al tiempo y determinar las unidades (Cornish-Bowden 1995). El cálculo de pendiente en la región de linealidad se ejecutó con la aplicación KinLab de Perkin-Elmer. 
La unidad se definió como la cantidad de enzima que libera un micromol de p-nitroanilida por minuto a $25^{\circ} \mathrm{C}$ a $\mathrm{pH}$ 6.20. Cuando la muestra estuvo diluida se realizó la corrección apropiada según el factor de dilución.

\subsection{Determinación de las condiciones de extracción}

\subsubsection{Evaluación del $\mathrm{pH}$ de extracción}

Para la evaluación del $\mathrm{pH}$ de extracción se realizó una extracción con buffer citrato-fosfato a $\mathrm{pH}$ 3.00, 4.00, 5.00, 6.00 y 7.00. Para ello se efectuó una dilución 1:10 de látex fresco en buffer.

Se tomaron alícuotas y se determinó la actividad en el momento de la extracción (0h) y a las 24 y 120 horas. Los ensayos se realizaron por duplicado.

\subsubsection{Evaluación del tiempo de extracción}

Se realizó una dilución 1:10 (w/w) de látex en buffer y se le proporcionó agitación constante mientras la temperatura se mantuvo a $5^{\circ} \mathrm{C}$ o a temperatura ambiente de $25^{\circ} \mathrm{C}$.

Se extrajo periódicamente una alícuota de la suspensión, la cual fue centrifugada a $5.000 \mathrm{~g}$ durante 10 minutos en una centrífuga $\mathrm{He}$ raus Sepatech Biofugue 200.

La actividad fue determinada en el sobrenadante, adicionalmente se determinó la cantidad de proteína extraída.

\subsubsection{Evaluación de la concentración del buffer y agentes protectores de la actividad}

Se ejecutó un diseño factorial completo de tres factores en dos niveles para medir los efectos e interacciones de los componentes, de acuerdo con el siguiente esquema: 
Tabla 4

Diseño factorial para evaluar los efectos del buffer y la concentración de cisteína y 2-mercaptoetanol

\begin{tabular}{cccc}
\hline Experimento & $\begin{array}{c}\text { Concentración } \\
\text { molar del buffer }\end{array}$ & $\begin{array}{c}\text { Concentración } \\
\mathbf{m M} \text { de cisteína }\end{array}$ & $\begin{array}{c}\text { Concentración mM } \\
\text { de 2-mercaptoetanol }\end{array}$ \\
\hline 1 & 0.1 & 0 & 0 \\
2 & 0.1 & 0 & 50 \\
3 & 0.1 & 50 & 0 \\
4 & 0.1 & 50 & 50 \\
5 & 0.2 & 0 & 0 \\
6 & 0.2 & 0 & 50 \\
7 & 0.2 & 50 & 0 \\
8 & 0.2 & 50 & 50 \\
\hline
\end{tabular}

Los experimentos se efectuaron por duplicado y la determinación de la actividad también se realizó por duplicado. Se hizo un análisis de varianza (Anova) en la aplicación Systat. Todos los gráficos se elaboraron en el programa Sigma Plot y muestran los valores promedio \pm desviación estándar.

\subsubsection{Precipitación, desalinización y liofilización de la enzima}

Una vez extraída la enzima en buffer suplementado con agentes reductores (cisteína o 2-mercaptoetanol) la enzima fue precipitada por adición de sulfato de amonio en cristales al sistema de extracción hasta una saturación del $45 \%$. El producto obtenido fue concentrado por centrifugación durante cinco minutos a $5.000 \mathrm{~g}$ y resuspendido en buffer hasta lograr un volumen final de 0.1 veces el volumen inicial del volumen inicial.

La solución obtenida se diafiltró contra agua destilada en una unidad de filtración tangencial minimate, con la finalidad de desalinizar el producto obtenido. La diafiltración se llevó a cabo a un flujo de 1.5 $\mathrm{ml}$ por minuto. La solución desalinizada fue precongelada a $-20^{\circ} \mathrm{C} \mathrm{y}$ liofilizada a $-45^{\circ} \mathrm{C}$ y 0.045 mbar de presión durante 6 horas. Se obtuvo un polvo de color blanco con bastante volumen. 


\section{RESULTADOS}

\subsection{Ensayos para determinación de proteína}

Los gráficos obtenidos al medir concentraciones crecientes de proteína contra la absorción medida muestran linealidad en el rango ensayado. La pendiente de las curvas es diferente para el caso de la albúmina de suero bovino (BSA) y la papaína. La papaína proporciona mejor linealidad en el ensayo, según se muestra en el gráfico 2 :

\section{Gráfico 2}

\section{Comparación de las curvas de calibración con papaína y albúmina de suero bovino (BSA)}

Determinación de cantidad de proteína por el método de Lowry: Albúmina de suero bovino versus papaína

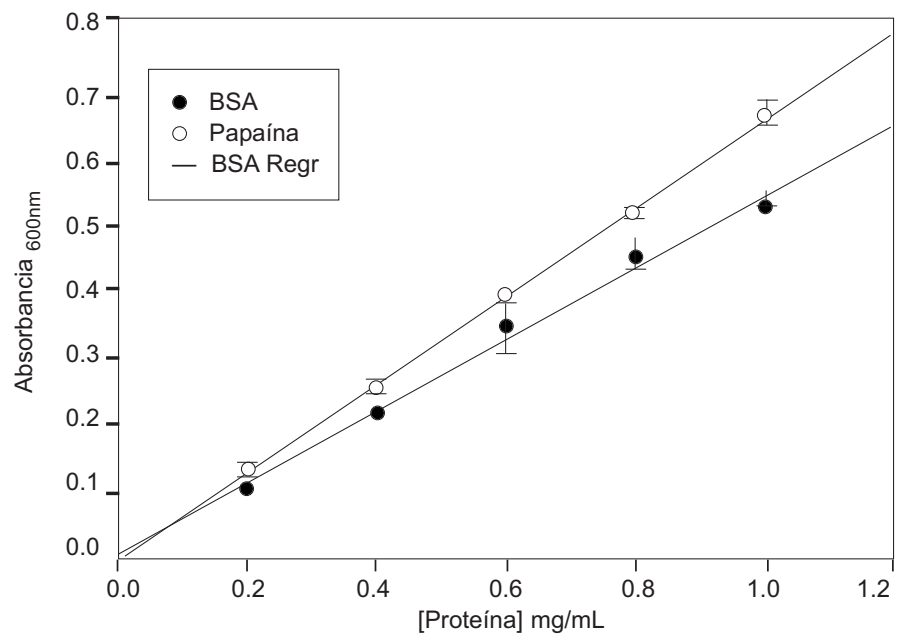

\subsection{Recuperación de actividad en función del pH}

Se logró recuperar un mayor número de unidades cuando el $\mathrm{pH}$ del buffer de extracción fue 3.00. Se encontró que a valores de $\mathrm{pH}$ más bajos (condiciones más ácidas) la recuperación fue mayor (gráfico 3). 


\subsection{Efectos de la concentración del buffer}

Para todos los tiempos, el buffer citrato-fosfato $\mathrm{pH} 3.0$ de mayor concentración molar produjo un más unidades recuperadas. Un mayor tiempo de extracción también produjo mayor recuperación (véase gráfico 4).

\section{Gráfico 3}

Recuperación de unidades de enzima a diferentes pH de extracción

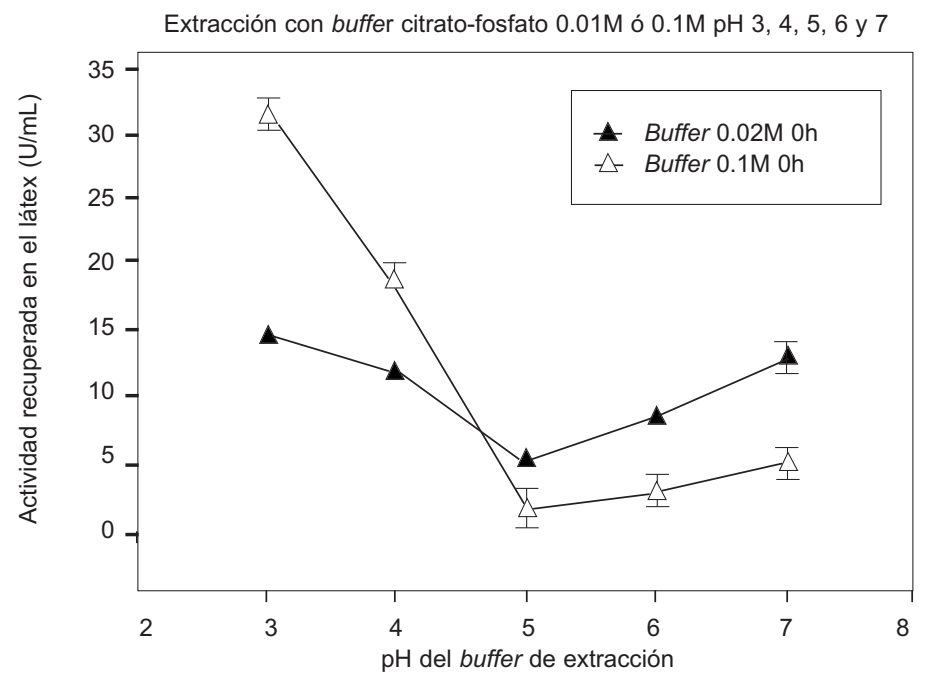

\section{Gráfico 4}

Efectos del tiempo de extracción en la recuperación de enzima

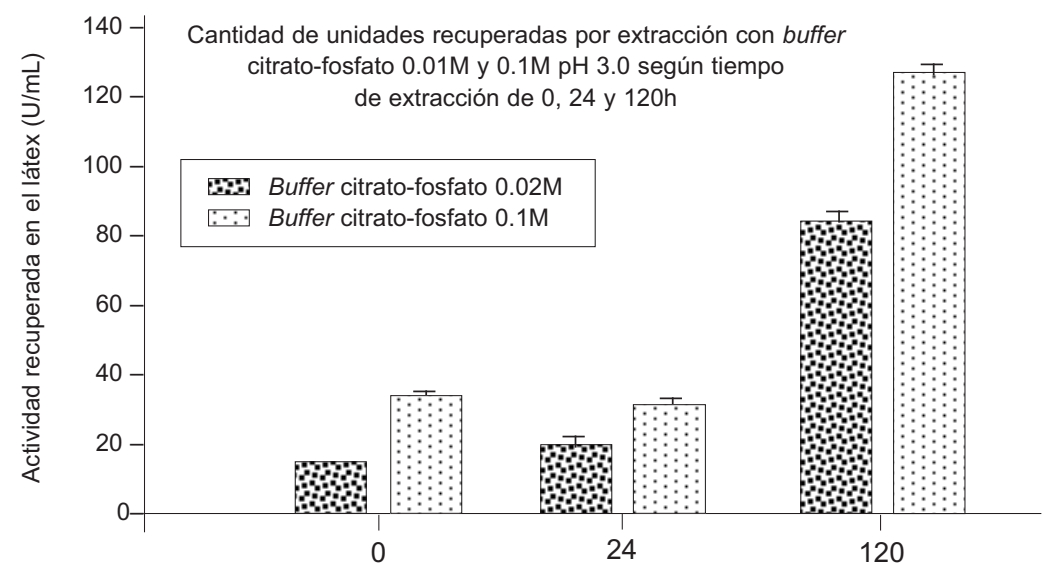




\subsection{Experimentos factoriales}

Se aplicó un análisis de varianza (Anova) a los resultados obtenidos del experimento factorial. Se muestran los efectos individuales de la concentración de buffer citrato-fosfato $\mathrm{pH} 3.0$, en concentración 0.1 y $0.2 \mathrm{M}$ (gráfico 5), la concentración de cisteína 0 y $50 \mathrm{mM}$ (gráfico 6 ) y la concentración de 2-mercaptoetanol 0 y $50 \mathrm{mM}$ (gráfico 7). Los efectos encontrados fueron significativos para las variaciones en la concentración de buffer $(\mathrm{p}=0.004)$ y 2 mercaptoetanol $(\mathrm{p}=0.013)$, mas no para las concentraciones ensayadas de cisteína $(\mathrm{p}=0.438)$.

\section{Gráfico 5}

Efecto de la concentración molar de buffer en la extracción de papaína $(p=0.004)$

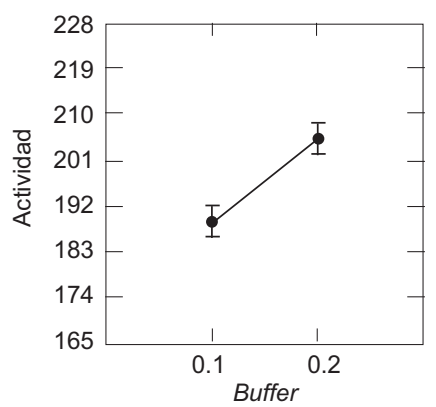

\section{Gráfico 6}

Efecto de la concentración de cisteína $(1=0 \mathrm{mM}$ y $2=50 \mathrm{mM})$ de cisteína en la extracción de papaína (no significativo)

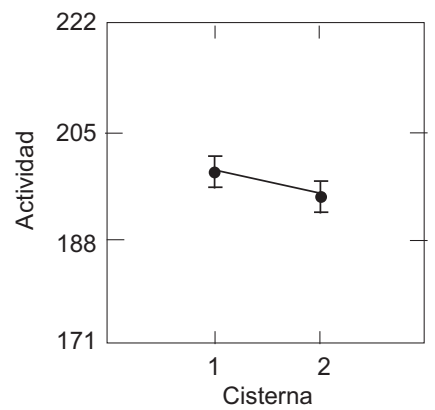

Gráfico 7

Efecto de la concentración de 2-mercaptoetanol $(3=0 \mathrm{mM}$ y $4=50 \mathrm{mM})$ en la extracción de papaína $(p=0.013)$

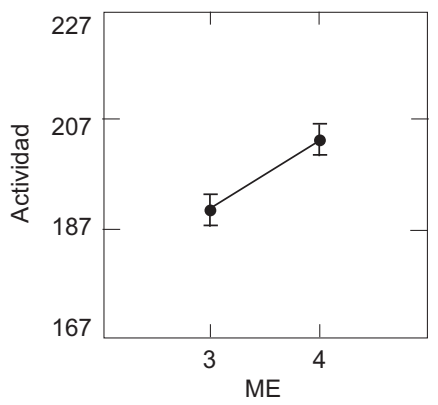


Se encontraron efectos independientes entre la concentración de buffer empleado y la concentración de cisteína (gráfico 8) o 2 mercaptoetanol (gráfico 9).

\section{Gráfico 8}

Efectos combinados de la concentración del buffer $(0.1$ y $0.2 \mathrm{M})$ y cisteína $(0$ y $50 \mathrm{mM})$
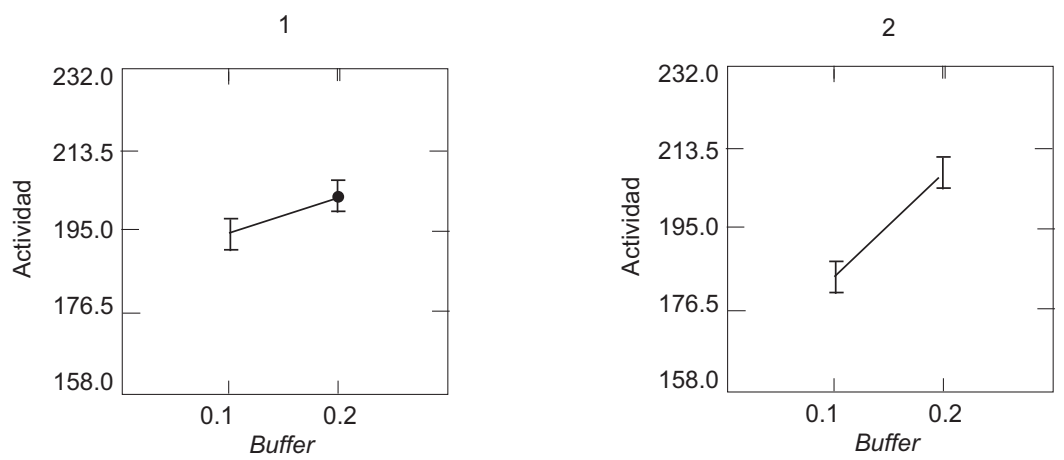

\section{Gráfico 9}

Efectos combinados de la concentración de buffer (0.1 y 0.2M) y 2-mercaptoetanol

3

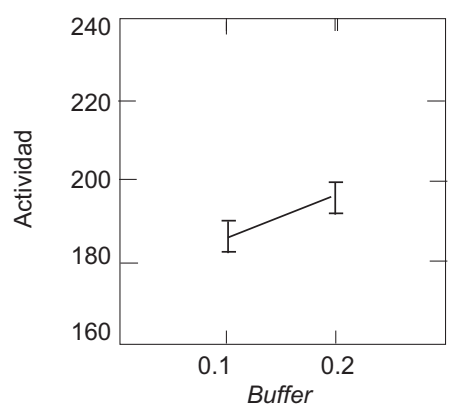

4




El gráfico 10 muestra que en ausencia de 2-mercaptoetanol (3) la adición de cisteína $(1=0 \mathrm{mM} ; 2=50 \mathrm{mM})$ produce un efecto negativo que puede neutralizarse en presencia de 2 mercaptoetanol $50 \mathrm{mM}$.

\section{Gráfico 10}

Efectos combinados de cisteína 0 y $50 \mathrm{mM}(1$ y 2$)$ y

2-mercaptoetanol 0 y $50 \mathrm{mM}$ (3 y 4)

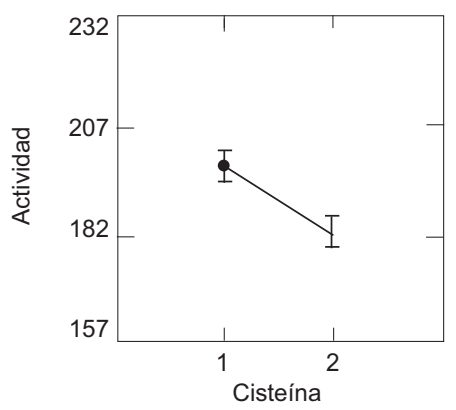

4

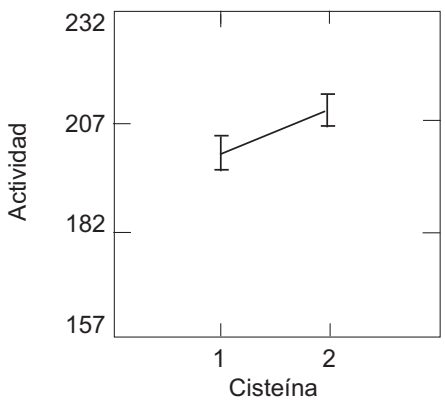

El gráfico 11 muestra los efectos combinados para los tres factores en los cuatro niveles ensayados (Buffer Citrato-Fosfato 0.1 y 0.2M, cisteína $0 \mathrm{mM}$ (1) y $50 \mathrm{mM}(2), 2$-mercaptoetanol $0 \mathrm{mM}$ (3) y $50 \mathrm{mM}$ (4). Se encontró una interacción significativa entre los tres factores $(\mathrm{p}=0.000)$.

\section{Gráfico 11}

Efectos combinados de la concentración de buffer 0.1 y $0.2 \mathrm{M}$, cisteína 0 y $50 \mathrm{mM}(1,2)$ y 2 -mercaptoetanol 0 y $50 \mathrm{mM}(3,4)$
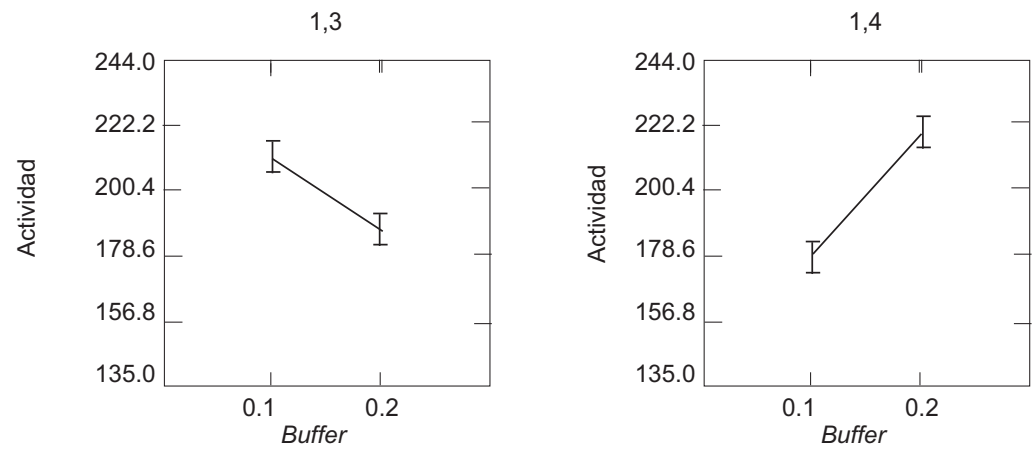
2,3

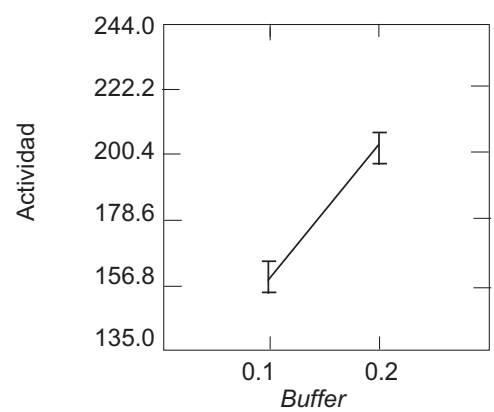

2,4

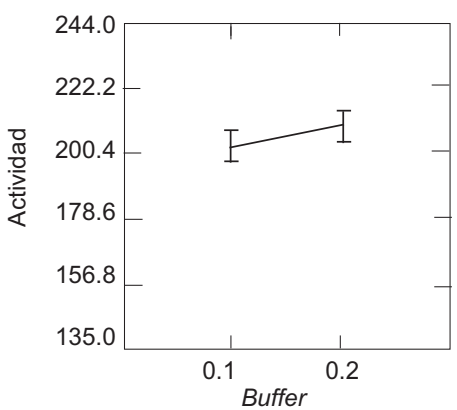

\subsection{Extracción de actividad en función del tiempo}

La curva de recuperación de actividad y proteína versus el tiempo a baja temperatura $\left(5^{\circ} \mathrm{C}\right)$ y agitación constante muestra un comportamiento clásico, esto es, pasado un tiempo los valores de actividad enzimática y concentración de proteína muestran una tendencia a un valor constante (gráfico 12). Esto indica que ya no es posible lograr una mayor extracción de proteína o una mayor recuperación de la actividad enzimática al aumentar los tiempos de extracción. La extracción se realizó bajo agitación constante, buffer citrato-fosfato $0.2 \mathrm{M}$ y $\mathrm{pH}$ 3.0. La relación látex: buffer de extracción fue 1:10. Idéntica a los experimentos de los gráficos 3 y 4.

Gráfico 12

Actividad recuperada frente al tiempo para látex de papaya mezclado con buffer bajo agitación constante a $5^{\circ} \mathrm{C}$

Fxtracellan a 5 graska Catilus

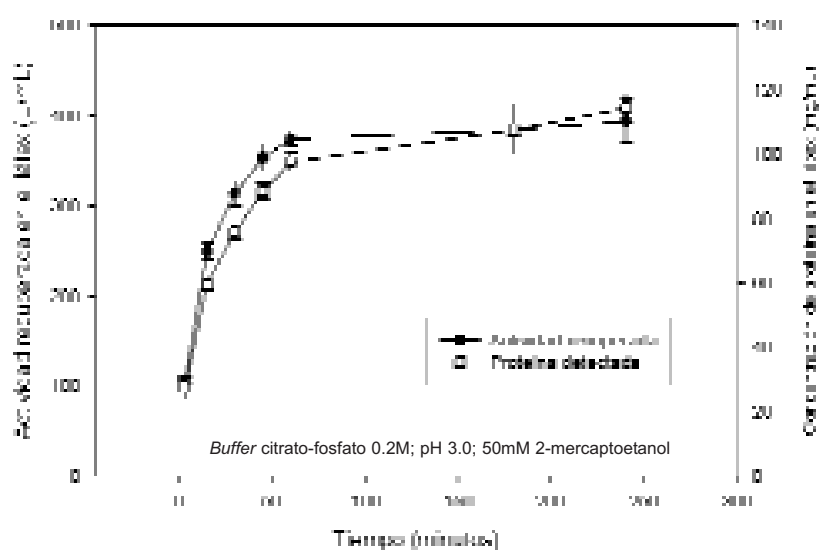


La extracción a $25^{\circ}$ muestra menores niveles de recuperación de actividad y pérdida de la actividad en el tiempo, que se evidencia por la disminución del número de unidades recuperadas al transcurrir el tiempo (gráfico 13). Este comportamiento es marcadamente diferente a los valores estables de actividad cuando el ensayo se realizó a $5^{\circ} \mathrm{C}$.

La cantidad de proteína recuperada al transcurrir el tiempo es muy similar en ambos casos (gráfico 14), en consecuencia la disminución de la actividad obedece a la desactivación de la enzima por la temperatura.

La extracción con buffer citrato-fosfato $0.2 \mathrm{M}$; pH 3.0; 50mM 2-mercaptoetanol y temperatura de trabajo a $5^{\circ} \mathrm{C}$ permitió recuperar 400 $\mathrm{U} / \mathrm{mL}$ de látex en 50 minutos.

\section{Gráfico 13 \\ Actividad recuperada durante extracción a $5^{\circ}$ y $25^{\circ} \mathrm{C}$}

Recuperación de actividad versus tiempo de extracción a temperatura alta y baja

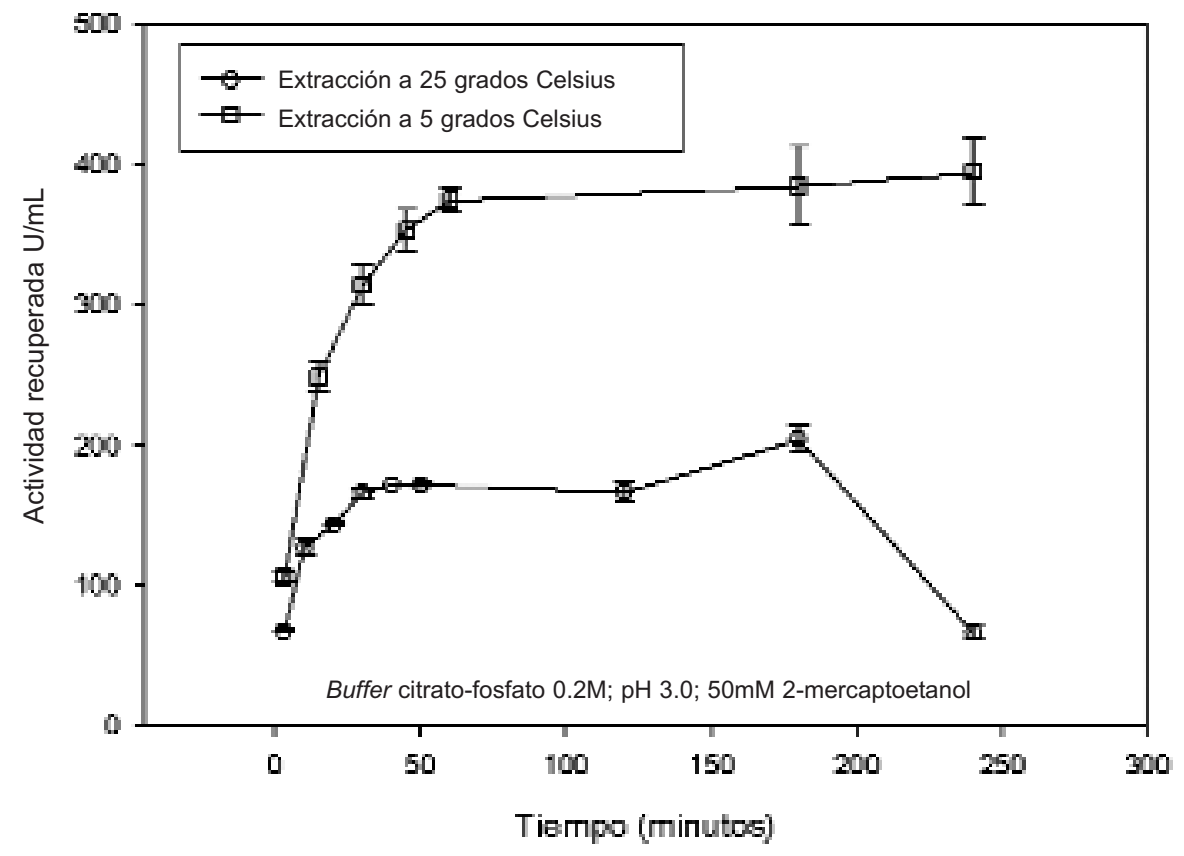




\section{Gráfico 14}

Concentración de proteína extraída a $5^{\circ}$ y $25^{\circ} \mathrm{C}$

Concentración de proteína extraída en función del tiempo de extracción a temperatura ambiente y baja temperatura



La medición de la actividad y proteína recuperadas permitió calcular el valor de actividad específica: el número de unidades enzimáticas recuperadas dividido entre la cantidad de proteína recuperada (una medición de la pureza del producto). Al aumentar el tiempo de extracción aumenta la cantidad de proteína recuperada, lo mismo ocurre con la actividad pero a un ritmo menor, es por ello que la pureza de producto recuperado disminuye (véase gráfico 15). Por ello, el tiempo de extracción para las condiciones ensayadas se estima entre 40 y 50 minutos. 
Gráfico 15

Actividad específica versus tiempo

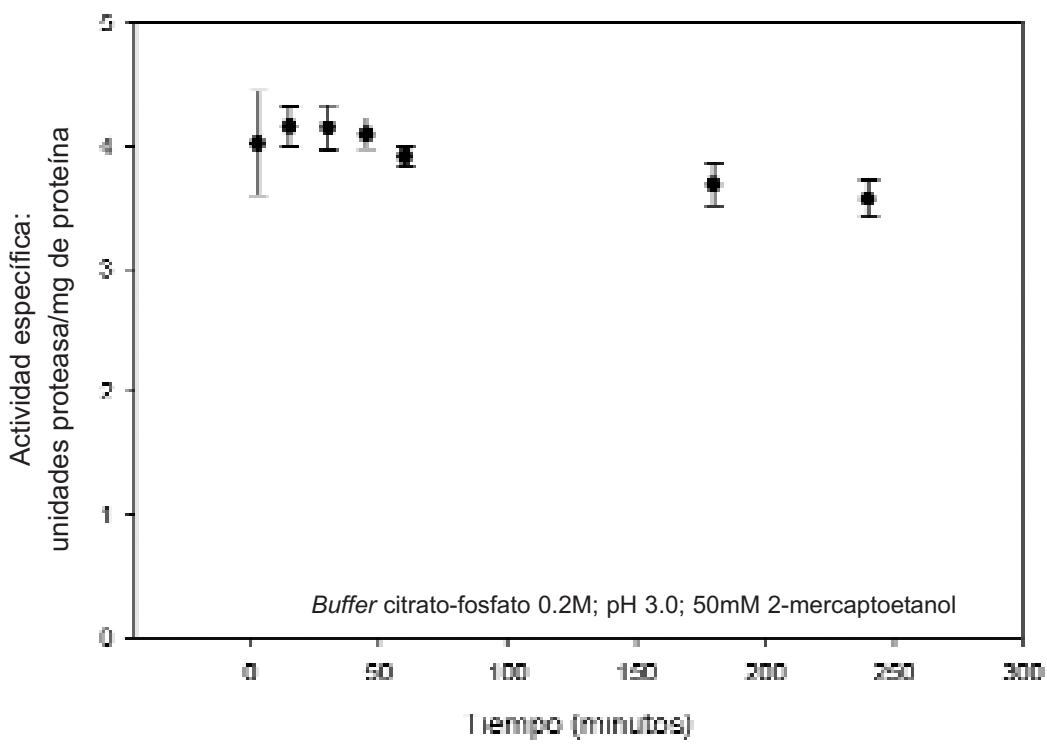

\subsection{Recuperación de la enzima}

El gráfico muestra la recuperación de la enzima después de la diafiltración (desalinización) y la liofilización del extracto obtenido con buffer citrato-fosfato 0.2M; pH 3.0; 2-mercaptoetanol 50mM.

El extracto inicial se toma como punto de partida y se le asignó un valor del 100\% al valor de actividad medido más alto. Las actividades medidas para el diafiltrado y el liofilizado se calculan como porcentajes del máximo inicial.

Los datos muestran promedios y desviaciones estándar, cada punto representa cuatro mediciones independientes de actividad en un intervalo de 3 minutos. También se incluye la determinación de la cantidad de proteína recuperada.

Se logró recobrar el 80\% de la proteína y se retuvo el 65\% de la actividad inicial. El producto obtenido es un polvo blanco muy soluble en agua. 


\section{Gráfico 16}

\section{Balance de masa para el proceso de extracción y purificación de papaína}

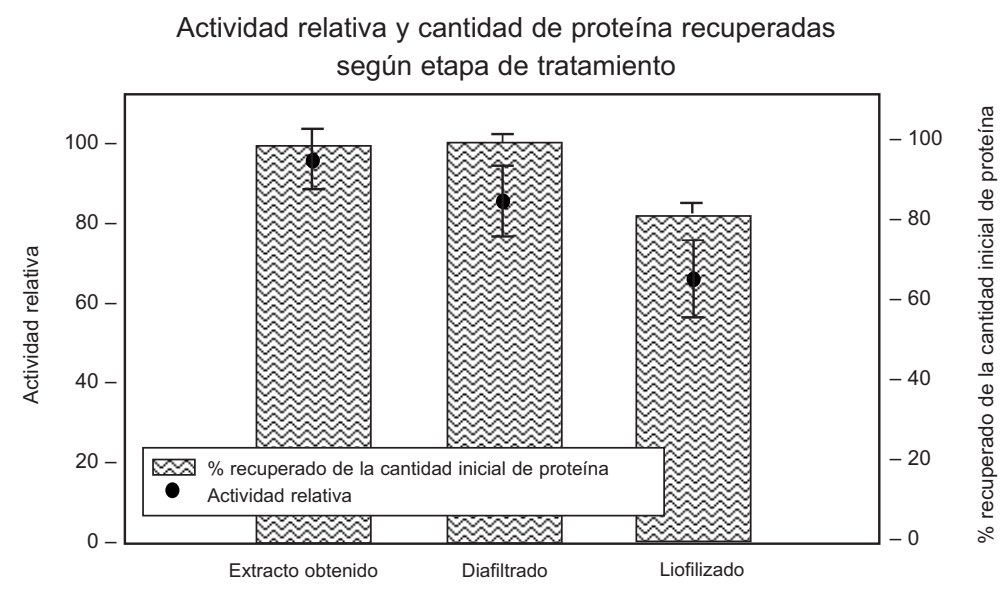

El gráfico 17 muestra el balance de materia para el proceso diseñado sobre la base de los resultados experimentales de la purificación de papaína a partir de látex de Carica papaya.

Cálculos preliminares

a) Buffer de extracción $\mathrm{pH}=3$ : $\quad$ por $100 \mathrm{~mL}$

$39.8 \mathrm{~mL}$ de ácido cítrico $\quad+\quad 10.2 \mathrm{~mL} \mathrm{de} \mathrm{Na}_{2} \mathrm{HPO}_{4} .12 \mathrm{H}_{2} \mathrm{O}$

$39.8 \mathrm{~mL} \times 19.21 \mathrm{~g} / 1000 \mathrm{~mL}+10.2 \mathrm{~mL} \times 71.7 \mathrm{~g} / 1000 \mathrm{~mL}$

Se agrega 2-mercaptoetanol a $50 \mathrm{mM}$

$50 \times 10^{-3} \mathrm{~mol} / \mathrm{L} \times 0.1 \mathrm{~L} \times 78.13 \mathrm{~g} / \mathrm{mol}=0.39065 \mathrm{~g}$ para $100 \mathrm{~mL}$ de $b u f f$.

Entonces, para preparar $100 \mathrm{~mL}$ de buffer se requiere:

$0.7646 \mathrm{~g}$ de ácido cítrico

$0.7313 \mathrm{~g}$ de $\mathrm{Na}_{2} \mathrm{HPO}_{4} .12 \mathrm{H}_{2} \mathrm{O}$

$0.39065 \mathrm{~g}$ de 2 -mercaptoetanol

Completar con agua. 
b) Solución de $\mathrm{NH}_{4} \mathrm{SO}_{4}$ al 40\%:

Se utiliza $0.243 \mathrm{~g} / \mathrm{mL}$

c) Rendimiento en la liofilización $=0.5 \mathrm{~g}$ de papaína purificada $/ 30$ $\mathrm{mL}$ de líquido alimentado.

Cálculos realizados para el balance de materia en base a los datos tomados el día 11 de diciembre del 2007.

Base: 8.2856 g de látex

Buffer de extracción

$$
\begin{aligned}
& \text { masa }=8.2856 \times 90 / 10=74.57 \mathrm{~g} \\
& \rho=1.009 \mathrm{~mL} \\
& \mathrm{~V}=73.90 \mathrm{~mL}
\end{aligned}
$$

Líquido con papaína que sale de la centrífuga 1:

$$
\begin{aligned}
& \text { masa }=75.314 \mathrm{~g} \\
& \rho=1.0112 \mathrm{~g} / \mathrm{mL} \\
& \mathrm{V}=74.4798 \mathrm{~mL}
\end{aligned}
$$

Sulfato de amonio aL $40 \%$

$$
\text { masa }=74.4798 \mathrm{~mL} \times 0.243 \mathrm{~g} / \mathrm{mL}=18.0986 \mathrm{~g}
$$

Masa total inicial en la etapa de precipitación $=75.314+18.0986$ $=93.4126 \mathrm{~g}$

Masa de líquido residual que sale de la centrífuga $2=88.9756 \mathrm{~g}$

Masa de sólidos con papaína que sale de centrífuga $2=4.4369 \mathrm{~g}$

Cantidad de agua para la dilución $=9 \times 4.4369=39.9321 \mathrm{~g}$

Líquido inicial de la liofilización

$$
\text { Masa total }=4.4369+39.9321=44.369 \mathrm{~g}
$$

volumen total $=40 \mathrm{~mL}$

Masa de papaína purificada $=0.5 / 30 \times 40=0.67 \mathrm{~g}$

El diagrama muestra un balance de materia expresado en kilogramos para una base de $1 \mathrm{~kg}$ de látex.

El factor de escalamiento fue: 1/8. 


\section{Gráfico 17}

Balance de masa en base a los procesos experimentales desarrollados

Extracción y purificación de papaína a partir del fruto de papaya balance de material para una base de 1 kilo de látex

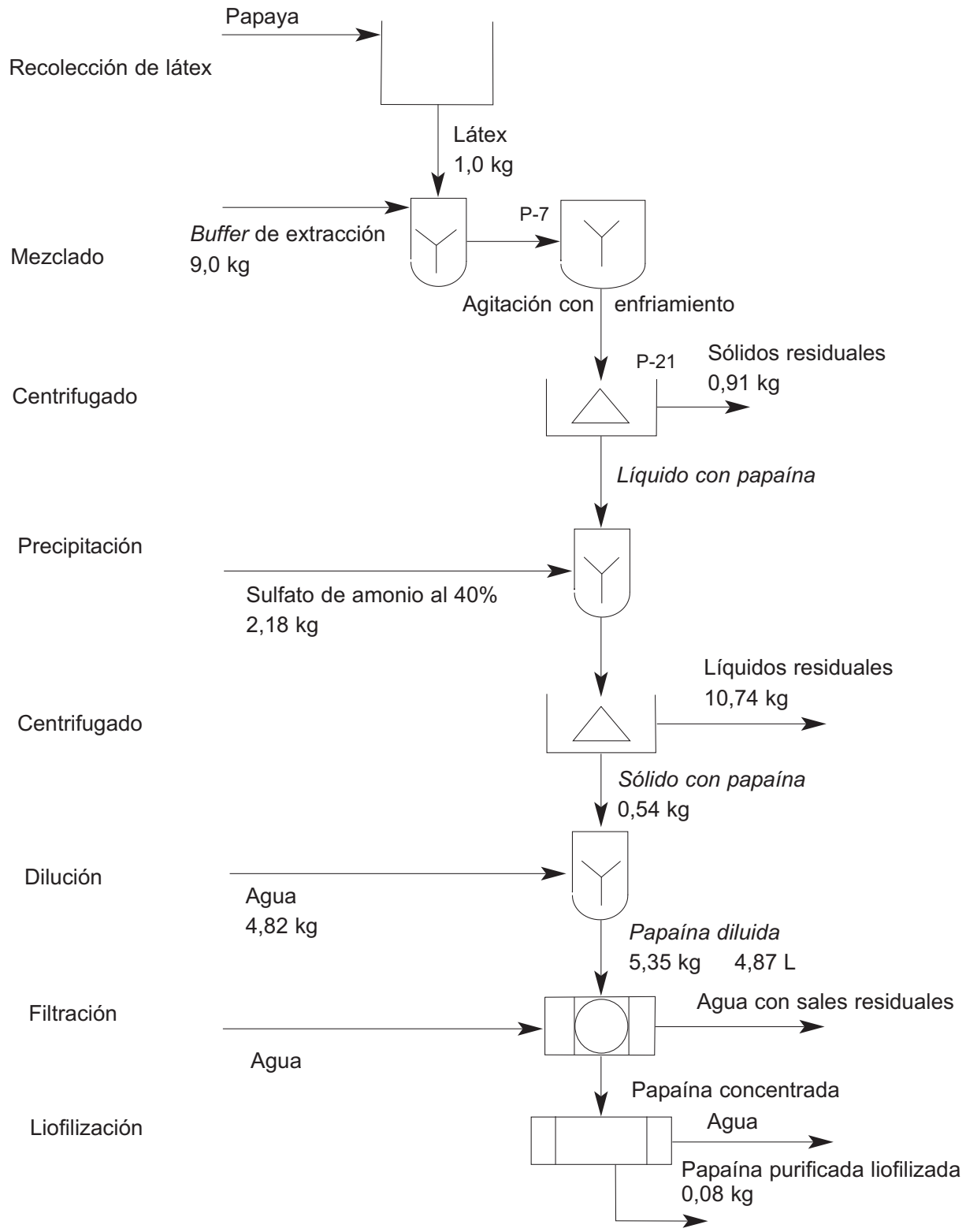




\section{Estimación de costos}

\section{Determinación de P.U}

Látex, g1

Agua bidestilada (I)

Ácido cítrico, $\mathrm{g}$

$\mathrm{Na} 2 \mathrm{HPO} 4.12 \mathrm{H} 2 \mathrm{O}, \mathrm{g}$

2-mercaptoetanol, g

Agua bidestilada, I

Costo buffer de extracción $\mathrm{pH}=3$ por $100 \mathrm{~mL}$

Por kg costo buffer $\mathrm{pH}=3$

Agitador magnético

Agitador magnético $\mathrm{x} \mathrm{hr}$

Electricidad (kwh)

Incubadora

Incubadora $\mathrm{x} \mathrm{hr}$

Electricidad kwh

Centrífuga

Centrífuga (x hr)

Electricidad (kwh)

Solución de amonio al $40 \%$

Sulfato de amonio

Agua bidestilada

Costo solución de amonio al $40 \%$

Filtración tangencial

Bomba peristáltica

Agitador magnético

Equipo

Electricidad (kwh)

Liofilización

Congelador

Electricidad (kwh)

Liofilizador

Electricidad (kwh)

Mano de obra

Investigador, $\mathrm{h}$

Auxiliar, $\mathrm{h}$
43200

$\begin{array}{cc}\text { Cantidad } & \text { Costo (US\$) } \\ 0.05 & 0.050\end{array}$

20

0.0427

0.85

0.7646

0.0542

0.0724

0.101

0.041

0.7313

0.39065

0.0985

0.85

0.053

0.039

0.084

0.218

2.180

21600

0.012

36000

1

36000

0.065

0.872

1.308

40.8

35.58

0.08

0.11

35.69

0.0373

1500

0.035

0.3

0.011

43200

6000

0.139

0.7

43200

0.7

14693

0.340

0.3

0.210

4

77.193

19.298

4

56.140

14.035 
Costos del proceso de purificación de papaína

Mezclado y agitación con enfriamiento

Látex, $g$

Buffer de extracción, g

Depreciación del equipo(hr) - agitador

Electricidad (kwh) - agitador

Depreciación del equipo(hr) - incubadora

Electricidad (kwh) - incubadora

Investigador

Auxiliar

Costo proceso 1 mezclado y agitación

con enfriamiento $(\$)$

Cantidad procesada

Costo unitario proceso 1 mezclado y agitación con enfriamiento (\$)

Factor de escalamiento

Cantidad

1.000

9.00

0.83

0.83

0.67

0.67

1.0

1.0

10.000

5.352

120.69

\section{Centrifugado}

Costo proceso 1 mezclado y agitación

con enfriamiento $(\$)$

Depreciación del equipo - centrífuga, $h$

Electricidad (kwh) - centrífuga, kwh

Investigador, $\mathrm{h}$

Auxiliar, $\mathrm{h}$

Costo proceso 2 centrifugado, US\$

Sólidos residuales, $\mathrm{kg}$

Cantidad procesado, kg

Costo unitario proceso 2 centrifugado, US\$

Factor de escalamiento

Costo del proceso, US\$

10.00

0.50

0.50

0.50

0.50

0.91

9.090

7.725

120.69

16.70

\section{Precipitación}

Costo proceso 2 centrifugado, US\$

Sulfato de amonio al $40 \%, \mathrm{~g}$

Depreciación del equip - agitador, $\mathrm{h}$

Electricidad (kwh) - agitador, Kwh

Investigador, $\mathrm{h}$

Auxiliar, $\mathrm{h}$

Costo proceso 3 de precipitación

Cantidad procesado, $\mathrm{kg}$

Costo unitario proceso 3 precipitación

Factor de escalamiento

Costo del proceso

9.09

7.72

35.69

0.17

0.17

0.02

0.00

19.30

14.04

11.270

13.726

120.65

84.47

\section{Centrifugado}

Costo unitario proceso 3 precipitación, US\$/kg

0.15

Electricidad - centrífuga, Kwh
P.U

0.05

2.18

0.02

0.30

0.08

0.30

19.30

14.04

5.35

53.52

0.02

0.01

9.65

7.02

70.22

4.00 
(continuación)

Costo proceso 4 centrifugado

Sólidos residuales, $\mathrm{kg}$

159.69

Cantidad procesado, $\mathrm{kg}$

10.74

0.54

Costo unitario proceso 4 centrifugado, US\$

295.73

Factor de escalamiento

121.71

US\$

Costo del proceso, US\$

5.01

9.27

\section{Dilución}

Costo proceso 4 centrifugado, US\$

0.54

295.73

0.08

159.69

4.82

0.019

0.41

Depreciación del equipo - agitador, $\mathrm{h}$

0.25

0.00

Electricidad - agitador, Kwh

0.004

0.00

Investigador, $\mathrm{h}$

19.30

5.79

Costo proceso 5 dilución

170.10

Cantidad procesado, $\mathrm{kg}$

5.36

Costo unitario proceso 5 dilución

31.74

Factor de escalamiento

120.70

Costo del proceso, US

10.41

US $\$ / \mathrm{kg}$

1.94

Filtración tangencial

Costo proceso 5 dilución

5.360

31.74

170.10

5.360

0.85

4.58

Depreciación del equipo - filtración tangencial, $h$

1.000

0.03

0.03

1.000

0.01

0.01

Investigador, $\mathrm{h}$

19.30

28.95

Auxiliar, $\mathrm{h}$

14.04

21.05

Costo proceso 6 filtración tangencial

224.73

Cantidad procesado, $\mathrm{kg}$

5.360

Costo unitario proceso 6 filtración tangencial

41.93

Factor de escalamiento

120.81

Costo del proceso, US\$

54.62

US\$

10.19

\section{Liofilización}

Costo proceso 6 filtración tangencial, US\$

5.360

41.93

224.73

Depreciación del equipo - precongelador, $\mathrm{h}$

1.00

0.139

0.14

1.00

0.210

0.21

Depreciación del equipo - liofilización, Kwh

10.00

0.340

3.40

Electricidad (kwh) - liofilización

0.210

2.10

Investigador, $\mathrm{h}$

10.00

19.30

38.60

Auxiliar, $\mathrm{h}$

Costo proceso 7 liofilización, US\$

14.04

70.18

Papaína liofilizada, kg

5.00

339.35

Costo unitario proceso 7 liofilización, US\$

0.08

4241.86

Rendimiento en la liofilización

0.0149

Factor de escalamiento

120.81

Costo del proceso de liofilización,US\$

114.62 


\section{DISCUSIÓN}

Para cuantificar la cantidad de proteína se realizó el ensayo de Lowry. En este tipo de determinación se usa con frecuencia la albúmina de suero bovino (BSA) como estándar para realizar una curva de calibración. Dado que en este tipo de métodos colorimétricos diferentes proteínas dan como resultado diferentes valores de absorbancia, es mejor utilizar la proteína de interés - papaína - en la construcción de las curvas de calibración (Stoschek, 1990). El gráfico 2 ilustra estas diferencias importantes en la respuesta, en especial en los límites altos de la determinación.

El látex colectado al hacer incisiones en los frutos verdes de Carica papaya se mezcló con buffer fosfato-citrato (Stoll y Blanchard, 1990) $0.02 \mathrm{M}$ en una proporción 1:10 a valores de $\mathrm{pH}$, que comprendieron desde el $\mathrm{pH} 3$ hasta el $\mathrm{pH}$ 7. Para evaluar la actividad recuperada se tomó una alícuota de cada extracto y se llevó a $\mathrm{pH} 6.20$ para determinación de la actividad (según protocolo descrito en la tabla 3). La máxima actividad recuperada se produjo a pH 3.0 a las 0,24 y 120 horas de haber realizado la extracción. El resultado se explica porque la papaína se encuentra inactiva a $\mathrm{pH} 3.0$ y no se produce la autolisis o autodigestión de la papaína por la propia papaína (Greenberg y Winnick, 1940); adicionalmente a este efecto de desactivación reversible se suma el efecto que los iones fosfato y citrato tienen sobre la papaína: favorecen la activación aunque esta no se encuentre al pH óptimo (Kimmel y Smith, 1954). El gráfico también indica que períodos más largos de extracción brindan mayor recuperación de la actividad.

La obtención de enzimas a partir de extractos vegetales requiere ambientes reductores (Gegenheimer, 1990), máxime si la enzima de interés necesita agentes que prevengan la oxidación (Baines y Brocklehurst, 1979; Monti, Basilio et al., 2000). Por ello, se evaluaron los efectos de dos agentes reductores comúnmente usados en la extracción de enzimas (Nitsawang, Hatti-Kaul et al., 2006): cisteína y 2-mercaptoetanol en un diseño factorial de 2 niveles y 3 factores. El tercer factor fue la concentración de buffer de extracción, con una fuerza iónica superior mayor (0.1 y $0.2 \mathrm{M})$ para aumentar la compatibilidad con las concentraciones de solutos halladas en el látex (Gegenheimer, 1990). Se encontraron diferencias significativas que favorecieron al 2-mercaptoetanol sobre la cisteína y también al buffer de extracción $0.2 \mathrm{M}$ sobre la concentración $0.1 \mathrm{M}$. 
La aplicación de cisteína, 2 mercaptoetanol o ambos es rutinaria en la extracción de las enzimas de clase similar a la papaína (cisteína proteasas). Los resultados encontrados bajo las condiciones de extracción utilizadas indican que la presencia de cisteína tiene un efecto negativo que no es significativo en la recuperación de la actividad.

Visto que la extracción no se realizó con agitación constante se repitieron las condiciones de extracción con buffer citrato-fosfato $0.2 \mathrm{M}$, $\mathrm{pH} 3.0$ y $50 \mathrm{mM} 2$-mercaptoetanol y se proporcionó agitación constante a $5^{\circ} \mathrm{C}$.

La curva de recuperación de actividad frente al tiempo aumenta de manera constante y el valor de actividad se estabiliza en el tiempo, lo mismo sucede con la cantidad medida de proteína extraída. Los valores de actividad recuperada (gráfico 12) son 4 veces más altos que lo logrado en los ensayos iniciales de extracción. Para el caso de la extracción a condiciones similares pero a $25^{\circ} \mathrm{C}$ la extracción de proteína sigue una curva similar, sin embargo, la actividad recuperada es menor y cae con el tiempo: las bajas temperaturas estabilizan la estructura de las enzimas y permiten una mejor recuperación (Fido, Clare Mills et al., 2004).

El extracto fue desalinizado y liofilizado para obtener un polvo de color blanco soluble en agua.

La integración de las diversas etapas, según se describe en el gráfico 16 , permite obtener $80 \mathrm{~g}$ de papaína a partir de $1 \mathrm{~kg}$ de látex fresco. El estimado de costos indica que la producción de $1 \mathrm{~kg}$ de papaína purificada tendría un costo de US $\$ 4.241,86$; el gramo de papaína purificada y liofilizada se encuentra en un rango que oscila entre US\$10 y US $\$ 60$, dependiendo de la pureza de la preparación y del uso que se le dará al producto.

\section{CONCLUSIONES}

- Se ha logrado diseñar un proceso de producción de papaína a partir de látex fresco de Carica papaya. El proceso tiene cuatro etapas: extracción, precipitación, desalinización y liofilización.

- La extracción de papaína de látex fresco del fruto verde de Carica papaya requiere buffer citrato-fosfato $\mathrm{pH} 3.0,0.2 \mathrm{M}, 50 \mathrm{mM}$ de 2-mercaptoetanol con relación 1:10 (látex:buffer) y agitación constante a $5^{\circ} \mathrm{C}$. 
- La enzima extraída se precipita con sulfato de amonio a una saturación del $45 \%$ y se desaliniza por diafiltración en un sistema de filtración tangencial.

- Al final de la liofilización se recupera el $80 \%$ de la proteína total y el $65 \%$ de la actividad original.

- El producto obtenido es soluble en el agua y puede ser estandarizada su comercialización para aplicaciones en la industria de alimentos.

- El proceso descrito permite obtener $80 \mathrm{~g}$ de papaína por kg de látex fresco.

- La producción de $1 \mathrm{~kg}$ de papaína purificada y liofilizada tiene un costo estimado de US $\$ 4.241,86$.

\section{BIBLIOGRAFÍA}

Baines, B. S. y K. Brocklehurst. "A necessary modification to the preparation of papain from any high-quality latex of Carica papaya and evidence for the structural integrity of the enzyme produced by traditional methods". Biochemical Journal 177, 1979.

Cornish-Bowden, A. Analysis of enzime kinetic data. Oxford: Oxford University Press, 1995.

- Fundamentals of Enzyme Kinetics. Cambridge: Portland Press, 1995.

Chaiwut, P.; Kanasawud, P. et al. "Solid-to-solid peptide synthesis by glycyl endopeptidase". Enzyme and Microbial Technology 40, 2007.

Duke, J. A. "Carica papaya L." [en línea].<http://www.hort.purdue.edu/ newcrop/duke_energy/Carica_papaya.html\#Description>. (Consulta: 21 de enero del 2008).

Duke, J. A. y J. L. DuCellier. CRC handbook of alternative cash crops. Boca Raton, FL: CRC Press, 1993.

Fido, R. J.; Clare Mills, E. N. et al. "Protein Extraction From Plant Tissues". Methods in molecular biology 244, 2004.

Gegenheimer, P. "Preparation of extracts from plants". Guide to Protein Purification 182. San Diego: Academic Press, 1990. 
Greenberg, D. M. y T. Winnick. "Plant proteases: pH-activity curves". The Journal of Biological Chemistry 2, 1940.

Kimmel, J. R. y E. L. Smith. "Crystalline papain. I. Preparation, specificity, and activation". J. Biol Chem 207, 1954.

Monti, R.; Basilio, C. A. et al. (2000). "Purification of papain from fresh latex of Carica papaya". Brazilian Archives of Biology and Technology 43, 2000.

Morton, J. F. Major medicinal plants: botany, culture and use. Springfield, IL: Charles C. Thomas, 1997.

Nitsawang, S.; Hatti-Kaul, R. et al. "Purification of papain from Carica papaya latex: Aqueous two-phase extraction versus two step salt precipitation". Enzyme and Microbial Technology 39, 2006.

Roberts, S. M.; Turner, N. J. et al. Introduction to biocatalysis using enzymes and micro-organisms. Cambridge: Cambridge University Press, 1995.

Sarath, G.; Zeece, M. Z. et al. (2001). "Protease assay methods". Proteolytic Enzymes. Nueva York: Oxford University Press, 2001.

Silva, L. G.; García, O. et al. "Changes in protein profile during coagulation of latex from Carica papaya". Brazilian Journal of Medical and Biological Research 30, 1997.

Stoll, V. S. y J. S. Blanchard. "Buffers: Principles and practice". Methods in Enzimology: Guide to protein purification 182. San Diego: Academic Press, 1990.

Stoschek, C. M. "Quantitation of protein". Guide to protein purification 182. San Diego: Academic Press, 1990. 